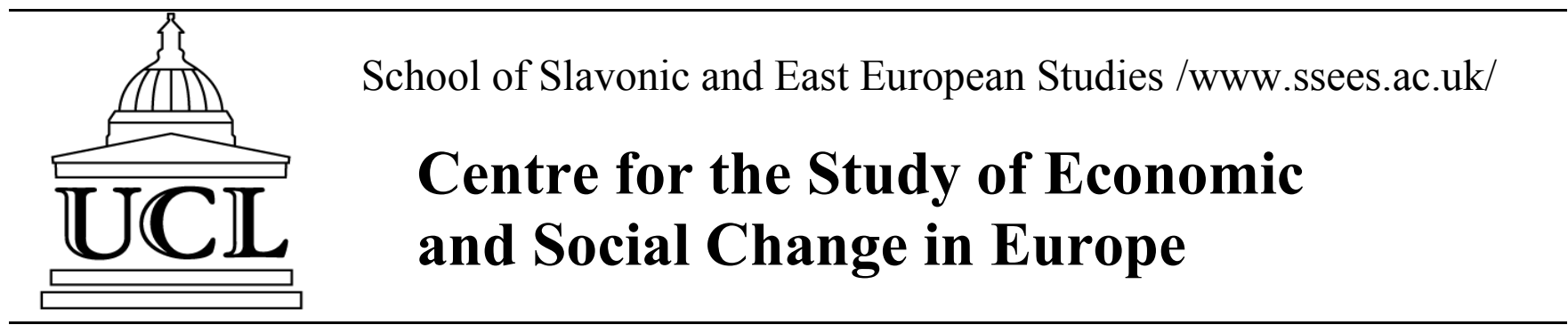

\title{
JOB CREATION AND JOB DESTRUCTION IN ESTONIA: LABOUR REALLOCATION AND STRUCTURAL CHANGES
}

Jaan Masso, Raul Eamets and Kaia Philips

\section{University College London}

School of Slavonic and East European Studies

Working Paper Series No 39

Key words: job creation, job destruction, labour reallocation, Estonia.

June 2004

University College London

School of Slavonic and East European Studies

Senate House, Malet Street, London, WC1E7HU

Tel: 44(0)20 76368000 (Switchboard)

Fax: 44(0)20 78628642

http://www.ssees.ac.uk/economic.htm 


\title{
JOB CREATION AND JOB DESTRUCTION IN ESTONIA: LABOUR REALLOCATION AND STRUCTURAL CHANGES
}

\author{
Jaan Masso, Raul Eamets, Kaia Philips ${ }^{1}$
}

\section{Introduction}

Several studies have documented that individual firms behave in different ways: many firms enter and exit each year, among entering firms many are forced to leave the market after some time, and also the (employment) growth of individual firms differs remarkably. The developments are largely idiosyncratic in the sense that they do not necessarily reflect the general industry dynamics or economy cycles (Bartelsman et al. 2003): there are rapidly growing firms in contracting industries and contracting firms in expanding industries. Firm dynamics relate to the concept of micro-level labour market flexibility (see Eamets et al., 2003a), i.e. the process of job creation and job destruction. High labour market flexibility is needed at the micro level so that jobs could move between sectors and firms in order to ensure effective resource reallocation and productivity growth. Aggregate productivity growth occurs both due to within-firm productivity growth and the

\footnotetext{
1 Jaan Masso (corresponding author), Ph.D student, University of Tartu, Faculty of Economics and Business Administration, Narva mnt. 4-A110, 51009 Tartu, Estonia. E-mail: Jaan.Masso@mtk.ut.ee

Raul Eamets, Ph.D, Associate Professor of Economics, University of Tartu, Faculty of Economics and Business Administration, Narva mnt. 4-A210, 51009 Tartu, Estonia. E-mail: Raul.Eamets@mtk.ut.ee

Kaia Philips, Ph.D, Associate Professor of Statistics, University of Tartu, Faculty of Economics and Business Administration, Narva mnt. 4-A210, 51009 Tartu, Estonia. E-mail: Kaia.Philips@mtk.ut.ee The technical work performed to obtain the results presented in the paper was partly carried out parting the framework of the World Bank's firm-level project. We thank Eric Bartelsman from Vrij Universiteit, Amsterdam for several comments on and discussions about the methodology during our participation in the aforementioned project, and for providing the computer programs used in the analysis. We acknowledge Karsten Staehr's, Tõnu Roolaht's, Kadri Ukrainski's comments on our paper and also participants of the seminar "Estonia - growth and restructuring of a new EU member" in University College London. We are grateful to Janno Järve from the Estonian Ministry of Economy and Communications and Indrek Künnapas from the Estonian Centre of Registers for information on the Estonian Business Registry. However, we alone take responsibility for all errors, inconsistencies etc. in the paper, so all criticism should be addressed to us only.
} 
reallocation of production factors from low-productivity units to high-productivity units (see e.g. Ahn, 2001).

It appears to be an empirical regularity that job creation and job destruction are simultaneous and parallel processes, with a relatively modest net employment change (Davis et al., 1997). A high rate of job reallocation ${ }^{2}$ is positive for economic growth (Aghion and Howitt, 1994), channelling labour resources from old and contracting firms to new and expanding ones. This ensures efficient use of resources and increased labour productivity. These issues are particularly relevant for the transition countries characterised by highly distorted factor allocations and many inefficient firms. Therefore, a high degree of reallocation of labour resources is expected as many new firms (greenfield firms, spin-offs, foreign entrants) are entering the market, while many existing state-owned enterprises are forced to leave if they are unsuccessful in restructuring or downsizing. However, a high degree of job reallocation may also have negative effects, at least in the short run, in terms of worker displacement and loss of earnings, possible losses in human capital during the period of non-employment, etc. The size of potential costs of job loss obviously depends on labour market policies; in the transition countries these costs could be higher than in the western countries, since the criteria for social benefits are rather strict; payments are flat-rate and relatively low. Konings et al. (2002) argue that at the aggregate level and in the long run benefits are more likely to compensate for individual costs.

Several papers studying job flows in transition economies have been published (e.g. Konings et al. (1996) about Poland; Basu et al. (1997), and Estrin and Svejnar (1998) about the Czech Republic, Slovakia, and Poland; Brown and Earle (2002) about Russia). The main findings of that literature, as summarised by Haltiwanger et al. (2003), are that 
(1) in early transition, job destruction dominates job creation, whereas at later stages job destruction and creation are roughly equal; (2) there was a large increase in worker flows ${ }^{3}$ when the transition began, (3) small and new private firms contribute to job creation disproportionately, while most of the job destruction occurs among state-owned firms, (4) within narrowly defined industries there is vast heterogeneity in job creation and destruction, but inter-industry reallocation is still more important than in western economies.

The purpose of this empirical paper is to analyse gross job flows in Estonia in the later period of the transition in order to find out whether the labour market has become more stagnant as suggested by other flexibility indicators (e.g. workers flows). As can be seen from Figure 1A and 2A in Appendix, workers' transition rates between the states of the labour market have declined. Also the probability of staying in the same state during a one-year period has increased and is relatively high ${ }^{4}$. As worker flows have declined in the course of the transition, one might expect job flows to have declined as well. The current paper reviews and reassesses the results from previous analyses of job flows in Estonia, using the unique database of the Estonian Business Registry. Analysing our data, we perceive no decline in job flows; so we will try to find the possible reasons for the very high job flow rate in Estonia. Finally, we analyse the influence of the government's policies and institutions on job reallocation.

Gross job flows in Estonia have been estimated by several authors using different data sets (e.g. Faggio and Konings 2003, Haltiwanger and Vodopivec 2002, Eamets 2003,

\footnotetext{
${ }^{2}$ Definitions are presented in Section 2.2.

${ }^{3}$ Worker flows (flows between places of employment and employment status) are related to job flows as follows. The sum of job creation and job destruction induces the maximum amount of worker reallocation induced by the flow of jobs between firms, while larger job creation and destruction equal the minimum worker reallocation (Davis et al., 1997).

${ }^{4}$ These are diagonal "flows" in the flow matrix, like UU, OO and EE movements. This means people have not changed their status during the year.
} 
Venesaar 2003). In this paper we employ a novel database from the Estonian Business Registry that comprises almost all firms that were registered in Estonia over the period 1995-2001. Therefore, one major advantage of our study is the comprehensiveness of our data, as it includes the population of firms from all sectors, regions, ages and size classes. Previous analyses, which used different enterprise data sets (AMADEUS, Statistical Office database, etc.), are likely to have underestimated the actual job flows, their data sets containing mainly larger enterprises and only a fairly limited number of smaller ones. However, in Estonia most enterprises are small and as Jurajda and Terrell (2002b) have observed, small start-up firms were the engines of job creation especially in the early transition. The Estonian Business Registry database allows us to document the gross job flows by different industries, whose net employment growth obviously varies. Our particular interest herein is to analyse whether it is job creation or job destruction that is the driving force behind this probably varying net employment growth.

Caballero and Hammour (1996) assert that when an efficient economy enters a recession, job destruction increases first, closely followed by a rise in job creation. As the economy is pulling out of the recession, job creation and job destruction again fall synchronously. These tendencies appear also when worker flows are analysed. Haltiwanger and Vodopivec (2002), using the Estonian Labour Force Survey data, show a rapid increase in both worker and job reallocation in the early 1990s with the annual worker reallocation rate exceeding $35 \%$ by 1993 . In Estonia, transition rates of workers between sectors and labour market states were very high in the early years of the transition, but since 2000 the labour market has become more stable and flow rates have declined (Eamets, 2003). According to Lehmann et al. (2002), also the displacement (job loss) in Estonia built up gradually during the initial period of transition (in 1992 up to 13\%) and declined after that, being broadly comparable with the Western countries' indicators. As worker flows 
have diminished, we expect that gross job flows should be also diminished as the transition matures.

Many shifts in employment across individual firms are idiosyncratic, i.e. with a relatively small proportion explained by shifts between industries, firm size, etc. The common finding in the literature is that firm performance and job flows are very heterogeneous even within narrowly defined industries and determined by idiosyncratic factors. One reason for heterogeneity is uncertainty about the demand for new products which generates experimentation; the latter in turn will cause heterogeneity. The other reasons are inter-firm differences in their managerial and entrepreneurial ability, and slow diffusion of information about new technologies, marketing channels, and consumer tastes (Davis et al., 1997).

Because job reallocation is important for growth, it is expedient to ask whether it is affected by government policies and institutions such as employment protection laws, bankruptcy and insolvency regulations, administrative burdens to start a new business, regulatory barriers to international trade and investment, etc. Scarpetta et al. (2002) studied empirically the role of policies and institutional settings in the OECD countries, finding that stringent product market regulations have a negative effect on new firms' productivity and market access. In addition, strict employment protection regulation, too, by reducing employment turnover, may lead to lower productivity and discourage the entry of firms (mainly small and medium-sized firms) to the market. Davis et al. (1997) discussed various policy implications, pointing out that high job destruction rates in all sectors underscore the importance of flexible workforce who is able to adapt to changes in location and skills requirements. These results have important implications for economic policy decisions, for example, those concerning employment protection laws, the 
administrative costs of firm establishment, etc. The present article documents the situation of these institutions in Estonia and makes some tentative proposals.

The rest of the paper is structured as follows. Section 2 describes the dataset and provides a brief review of the definition of job flow measures. The empirical results (aggregate job flows and job flows by employer's characteristics), as well as the results from the decomposition of the excess job reallocation and analysis of the institutional effects on job flows are presented in Section 3. The final section concludes with policy implications.

\section{Data and definitions}

\subsection{Description of data}

A job flow analysis assumes the availability of firm-level data. In Estonia, such data are gathered by the Statistical Office and the Business Registry. In addition, also the Estonian Tax Board has some information due to its activities ${ }^{5}$. Performing the gross job flow analysis we use the database of the Estonian Business Registry that during the time of the study covered the years 1995-2001. This database includes all officially registered firms in Estonia. The total number of unique firm registry numbers in the database is almost 52,000 ; however, for each distinct year the number of firms is substantially smaller due to frequent entry and exit. In the Appendix, Figure A3 shows the evaluation of the total number of firms in the Registry. As we can see, the number of business entities increases over time and over seven years the number has more than tripled. However, for 1995 and 1996 the coverage may be less perfect and that may have been created by spurious entry.

\footnotetext{
${ }^{5}$ For the availability of firm-level data in Estonia, see also Eamets and Masso (2003).
} 
Our dataset is in several aspects more comprehensive than those used by previous studies. First, it includes very small firms as well, there being no size threshold. Table A1 in Appendix presents the distribution of enterprises by the number of employees and their respective employment shares. By comparison, the database of the Estonian Statistical Office used by Eamets (2003) and Venesaar (2003) contained 7,800 firms, including all the enterprises owned by the state and local governments, and all the corporate enterprises employing at least 20 employees; from the rest of the enterprises owned by Estonian and foreign private entities a simple random sample was drawn and surveyed. The AMADEUS database of European firms, used, for instance, by Faggio and Konings (2003) to study job flows in the Central and Eastern European countries, must have been heavily censored, as it included only firms employing more than 100 employees, whose total assets were more than 16 million or operating revenues more than 8 million USD. Haltiwanger and Vodopivec (2002) and Vodopivec (2003) derived job flows indicators using the Estonian Labour Force Survey data, which was possible due to their rather detailed information on the reasons for terminating the employment relationship.

Second, our data set includes all three economic sectors (agriculture, manufacturing and services) as well as information about industries (see Table A2 in Appendix about the distribution of firms across industries $\left.{ }^{6}\right)$. Frequently, researchers have access only to manufacturing firms' data, or the secondary sector data. Relying on the Business Registry data we can also analyse gross job flows by regions and by ownership type (Table A3 and A4 in Appendix present the distribution of firms in Estonia respectively by regions ${ }^{7}$ and ownership categories).

\footnotetext{
${ }^{6}$ As an industry classification, we use the OECD STAN classification (see e.g. Bartelsman and Barnes, 2001). It is based on NACE (Statistical Classification of Economic Activities in the European Community) like the Estonian EMTAK code (Classification of Economic Activities of Estonia), so the concordance between the two is straightforward.

${ }^{7}$ For this analysis we used EU NUTS 3 (Nomenclature of Territorial Units for Statistics) classification.
} 
Third, the unique feature of our dataset is that it also provides information on transactions (mergers, acquisitions, divestitures, etc.). Although the presence of transactions in the data may be important for the results (even if there are just a few of them, but these few transactions concern large firms), it is often impossible to account for them in empirical studies. Table A5 in Appendix shows that the most frequent kind of transactions has been the change in the registry code due to transfer from the Enterprise Registry to the Business Registry. The transactions are more important when weighted by employment (e.g. mergers of large firms). We made the following corrections in the data. In case of "predecessor", the observations for old and new "ID numbers" were treated as one firm. For acquisitions, the employment of the acquired firm before the date of transaction was added to the employment of the acquiring firm. In other cases (mergers, spin-offs, breakups) we considered the transactions as true entry and exit.

The average firm size (by number of employees) in Estonia is very close to the OECD average, however, the standard deviation is much smaller, for example, due to the smaller number of very large firms in Estonia (see Table A6 and A7 in Appendix). The average firm size increased between 1995 and 1997 and decreased thereafter (that pattern is observable in agriculture, manufacturing, and services). The central variable in our analysis is the number of employees in a firm. In the available data we can observe only the increase or decrease in the given firm's total number of employees, but get no information about how many people were hired and fired during a year. Another drawback of our data is that employment data are missing in a rather considerable number of observations (e.g. in $29 \%$ of observations in the year 2000 and $22 \%$ of observations in 2001). 


\subsection{Definitions}

The definitions of rates of gross and net job flows have by now become fairly standard in the literature on job dynamics (e.g. Davis and Haltiwanger, 1999). Gross job creation (pos) is defined as the sum of all employment gains in all expanding firms, while gross job destruction (neg) is the sum of all employment losses in all contracting firms in an economy, sector or region. Usually these gross job flows are expressed as rates by dividing them by the total amount of jobs available in an economy, sector or region. The sum of the gross job creation rate and the gross job destruction rate is the gross job reallocation rate (gross), while the difference is the net aggregate employment growth rate (net) that can be observed in aggregate statistics. A measure of reallocation of jobs, which is over and above the amount of job reallocation necessary to accommodate a given net aggregate employment growth rate is the excess job reallocation rate and is defined as the gross job reallocation rate minus the absolute value of the net aggregate employment growth rate (excess).

While most of these job flow measures have generally accepted interpretations also in transition contexts, one of them, namely, the excess job reallocation rate, is somewhat more controversial. While some authors understand it as a measure of deep restructuring, others interpret it more conventionally as a sign of heterogeneous firm behaviour within a given sector and of genuine labour reallocation within a sector (e.g. Konings et al., 2002).

We also look at the one-year and two-year persistence rates of job creation and job destruction. The one-year (and respectively two-year) persistence rate of job creation is the fraction of jobs created in year $t$ that are still filled on the sampling date one year (two years) later. The one-year persistence rate of job destruction is the fraction of jobs that do not reappear on the sampling date a year later. These persistence rates indicate whether the 
observed job flows are of a temporary or more permanent nature, an issue of particular relevance in transitional contexts.

Following the procedure of Davis and Haltiwanger (1992), we also investigate how the overall excess job reallocation decomposes into the 'between' and 'within' components. The former is measured by summing across sectors the deviation of net employment change for every sector from the absolute net employment change of the overall economy. The latter, the 'within' component, is measured as the sum over sectors of the excess job reallocation in each sector.

The formula for this decomposition is as follows (as derived by Davis and Haltiwanger, 1992):

$\operatorname{gross}_{t} \cdot N_{t-1}-\mid$ net $_{t} \cdot N_{t-1} \mid=\left(\sum_{s=1}^{S} \mid\right.$ net $_{s, t} \cdot N_{s, t-1}|-|$ net $\left._{t} \cdot N_{t-1} \mid\right)+\sum_{s=1}^{S} \operatorname{excess}_{s, t} \cdot N_{s, t-1}$,

where $N_{s, t}$ is the employment in sector $s$ in time $t ; S$ is the total number of sectors; gross $s_{t}$, $n t_{t}$ and excess $_{t}$ denote respectively gross, net and excess reallocation rates. The left-hand side of the formula is the total job reallocation over the amount of net employment change (the excess job reallocation in the economy). The first term in the right-hand side shows the component of excess job reallocation due to the employment shifts between sectors over the net employment change (calculated as the absolute value of employment changes in sectors summed over all sectors minus the net employment change in the total economy). The second term in the right-hand side is the component due to excess job reallocation within sectors. 


\section{Patterns of job creation and destruction in Estonia}

\subsection{Macroeconomic environment}

Estonia is often referred to as one of the most successful transition economies. At the beginning of the 1990s, the Estonian economy was closely bound up with the raw materials and product markets of the former Soviet Union, and at the beginning of the transition period the structure of the economy was shaped according to the economic needs of the Soviet Union. Drastic changes (liberalisation of prices, introduction of own currency, using a currency board system, requirement for a balanced state budget, freedom in foreign trade, etc.), which took place in the period 1991-92, created a completely new environment for business activity and are viewed as the start of serious reforms and restructuring of the Estonian economy. The highest GDP growth rate was achieved in 1997. This period in the development of the country's economy was marked with relatively steady economic growth until the middle of 1998 . Then came a banking crisis in Estonia, followed by the 1998 Russian crisis, which led to stagnant economic growth in 1998 and a recession in $1999(-1,1 \%)$. One by-product of the recession was the second wave of restructuring in the Estonian economy. Since the end of 1999, growth has been restored. The GDP growth was $6.4 \%$ in $2000,5.1 \%$ in 2001 and $5.8 \%$ in 2002. According to the Estonian Statistical Office, the average economic growth was 5.2\% over the period 1995-2002. While the Estonian monetary and fiscal policies are rigid, the social policy and particularly labour policy have been very flexible. By flexibility we mean that the labour policy has been (financially) limited, and the low unemployment benefit works as a strong disincentive for a long job search period. 


\subsection{Job creation and destruction at the aggregate level}

We start the review of the empirical results with the job flows (job creation and destruction) indicators. This strand of empirical research has gained importance since the paper by Davis and Haltiwanger (1992) was published and has produced a lot of evidence from the Western countries. By now several surveys have also appeared on the transition countries, including Estonia. For example, Haltiwanger and Vodopivec (2002) analyse the role of labour market flexibility for Estonia and find that Estonia's transition process has been successful. The country's rapid reforms have led its economy to sustainable growth and to rates of job reallocation similar to those reported for western economies. Next, we will review and compare our results vis-à-vis the earlier literature.

The empirical literature has shown that the destruction (due to the exit of old firms or contraction of surviving firms) and creation of jobs (either due to the entry of new firms or the expansion of the existing units) are largely simultaneous processes (Davis et al., 1997) with a relatively modest change in total employment, and that is what we can also see in our data (see Figure 1).

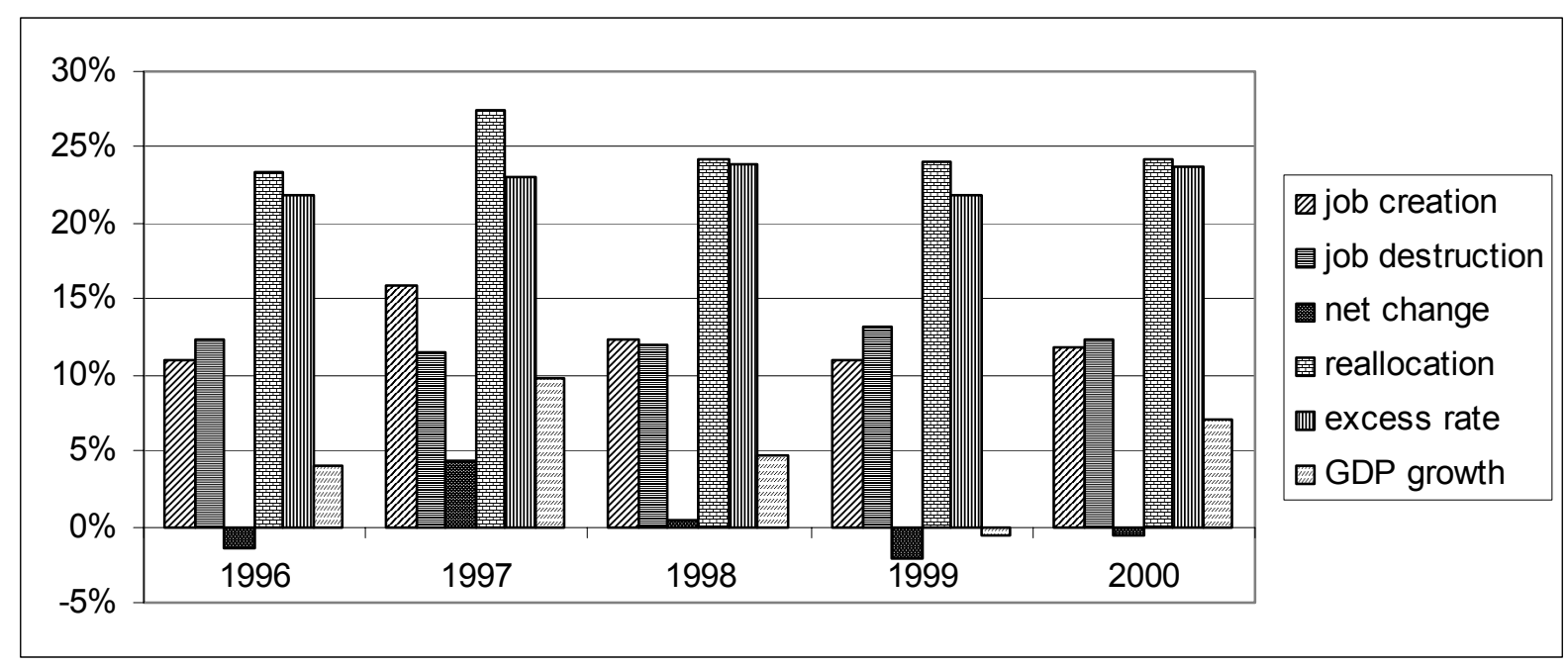

Figure 1. Indicators of job flows in Estonia, 1996-2000 (\% of employment)

Source: Estonian Business Registry database, authors' calculations 
Our estimates are higher than those from previous studies on Estonia (see Figure 2). This is an expected result as our dataset is more representative in respect of the population of all firms. The excess rate remains higher even if we exclude small firms (less than 20 employees) from our calculations. According to Faggio and Konings (2003), the excess rate for 1996-1997 was 16\%; our average for firms with more than 100 employees is quite close to that (18\%) figure.

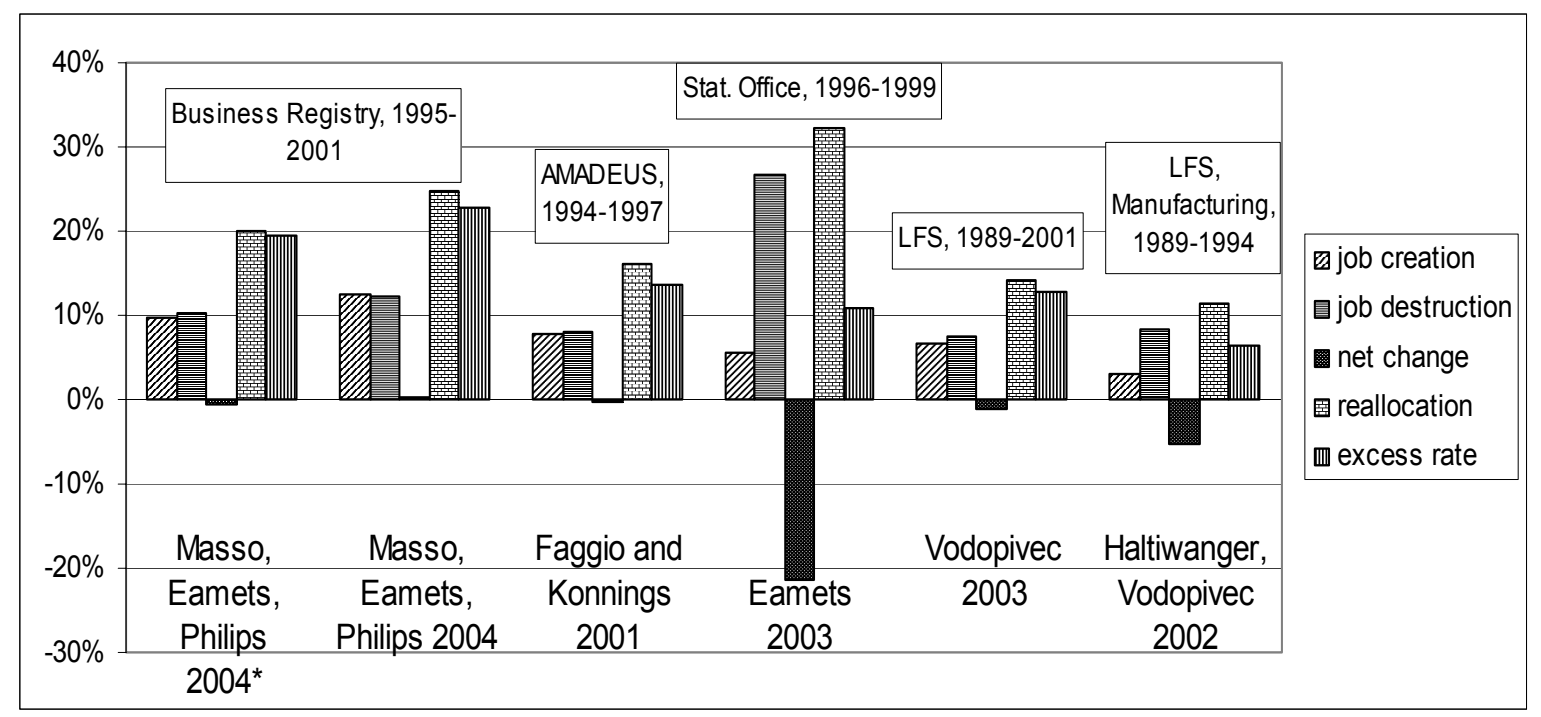

Figure 2. Job flows indicators in Estonia drawn from different studies (\% of

\section{employment)}

Note. LFS denotes Estonian Labour Force Survey; AMADEUS is an international database of firm-level data. "Masso, Eamets, Philips 2004*" denotes results from the Estonian Business Registry database using only firms having at least 20 employees.

Source: Authors' calculations; Eamets 2003; Vodopivec 2003; Haltiwanger and Vodopivec 2002.

By comparison with the papers by Eamets (2003) and Venesaar (2003), our numbers are more reliable. Though the data from the Statistical Office included some extra useful indicators (e.g. firm's date of establishment), the observed negative employment change in the earlier findings cannot describe the economy as a whole and seems to have been caused by data problems. Our job flows estimates are rather stable over the years, while 
Faggio and Konings (2003) found that in Estonia the excess rate increased from 9\% in 1994 to $18 \%$ in 1998 . The estimates by Vodopivec (2003) based on the Estonian Labour Force Survey data declined from $18 \%$ in 1994 to $12 \%$ in 1999. An explanation to our results could be that while the worker flows might decline as the transition moves towards its end, the emergence and development of small and medium-sized enterprises sector has helped maintain the overall high firm dynamics and flexibility.

Our estimation of the gross job flows, $25 \%$, is rather high in international comparison, and similar to the level of the United States. The most important job flow indicator, the excess rate, is $23 \%$, indicating about rather high labour market flexibility in Estonia compared to the CEE and Western European countries (see Figure 3). The excess rate is somewhat lower if we exclude small firms, but still almost equal to its US counterpart.

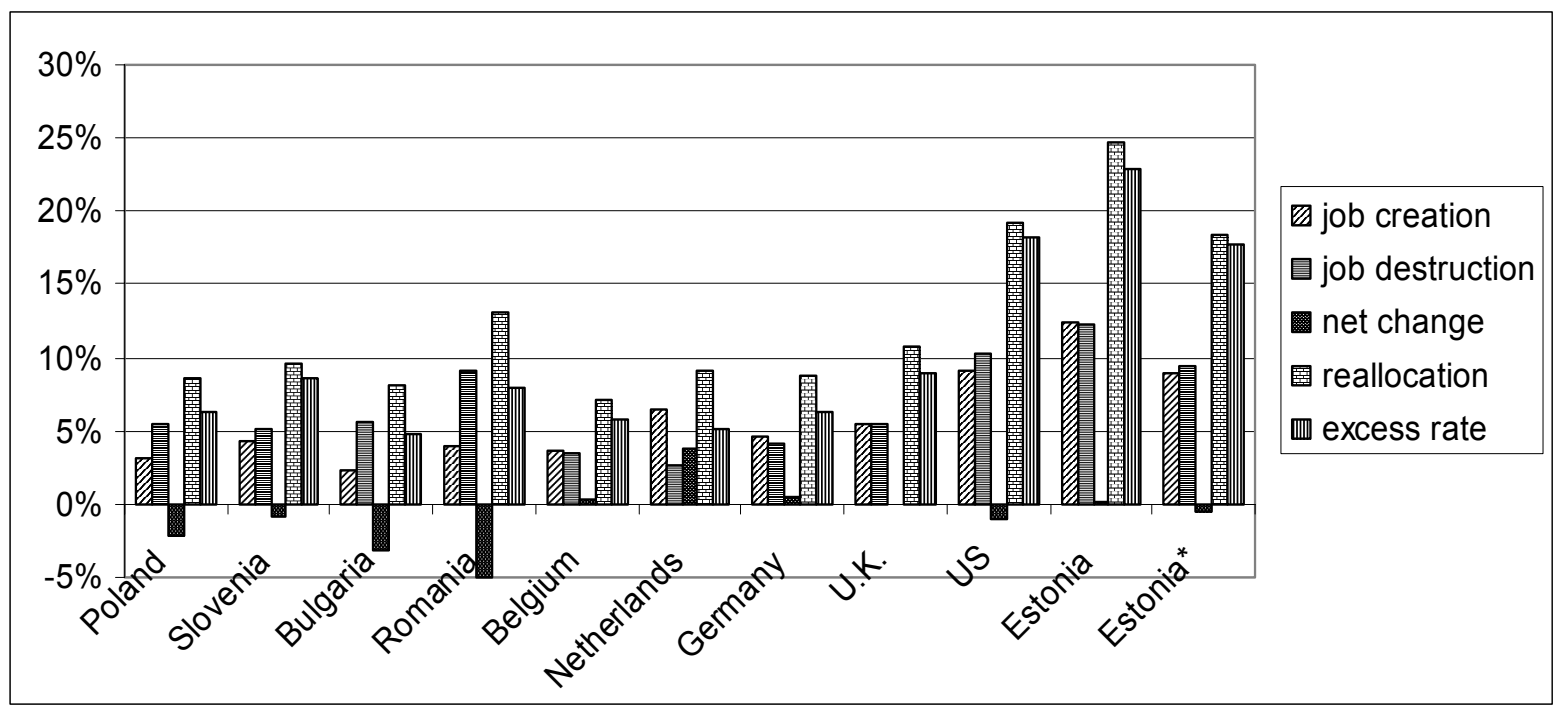

Figure 3. Indicators of job flows in Estonia in international comparison (\% of employment)

Note. For Estonia, the data were from 1995-2001; for the USA from 1973-1988; for Belgium from 19891995; for the Netherlands and Germany from 1988-1995; for the UK from 1987-1995; for Romania from 1995-1997; for Poland, Slovenia and Bulgaria from 1994-1997. Estonia* denotes the results from the Estonian Business Registry database using only firms having at least 100 employees.

Source: Estonia: authors' calculations; USA: Davis et al. 1997; other countries: Faggio and Konings, 2003 


\subsection{Job creation and destruction by employers' characteristics}

Next we will analyse job flows by employers' characteristics (see Table 1). The negative relationship between job flows and firm size illustrates that in order to understand job flows in the whole economy, we need, besides data on large firms, those on small and micro firms. However, this relationship is not linear; the excess rate diminishes rapidly from micro firms (less than 10 employees) to firms with 50-99 employees, but thereafter more gradually.

The positive (negative) net employment growth among small (large) firms may reflect both the learning effect of small firms, i.e. a firm learns about its potential profitability from the realised profits (passive learning, see Jovanovic (1982)) or actively explores the economic environment and invests to improve its ability to earn profits (active learning, Ericson and Pakes (1995). On the other hand, the negative growth of large firms may reflect downsizing due to changes in industrial structure and production technologies in the course of the transition processes. Table 2 discloses that small and medium-sized firms account for ca. $86 \%$ of job creation and $79 \%$ of job destruction. Though small firms create more jobs, they seem to be less permanent. Compared to the classic study of Davis et al. (1997), our job creation persistence rates are low for small firms, but similar for large firms. Our job destruction persistence rates are much lower than in Davis et al. (1997), i.e. many destroyed jobs will be recovered after some time, which indicates rather high labour market flexibility. 
Table 1. Job flows by employers' characteristics

\begin{tabular}{|c|c|c|c|c|c|}
\hline & pos & neg & net & gross & excess \\
\hline Total average & 0.12 & 0.12 & 0.00 & 0.25 & 0.23 \\
\hline \multicolumn{6}{|l|}{ Employer's size class } \\
\hline $1-9$ & 0.26 & 0.18 & 0.08 & 0.44 & 0.36 \\
\hline $10-19$ & 0.16 & 0.13 & 0.03 & 0.28 & 0.26 \\
\hline $20-49$ & 0.12 & 0.12 & 0.00 & 0.24 & 0.24 \\
\hline $50-99$ & 0.10 & 0.11 & -0.01 & 0.21 & 0.20 \\
\hline $100-249$ & 0.09 & 0.10 & -0.01 & 0.19 & 0.19 \\
\hline $250-499$ & 0.09 & 0.09 & 0.00 & 0.18 & 0.18 \\
\hline More than 500 & 0.08 & 0.09 & -0.01 & 0.18 & 0.17 \\
\hline \multicolumn{6}{|l|}{ Industry } \\
\hline Agriculture & 0.07 & 0.16 & -0.08 & 0.23 & 0.14 \\
\hline Manufacturing & 0.10 & 0.09 & 0.01 & 0.20 & 0.18 \\
\hline Construction & 0.14 & 0.15 & -0.02 & 0.29 & 0.26 \\
\hline Business services & 0.15 & 0.14 & 0.02 & 0.29 & 0.27 \\
\hline Trade & 0.16 & 0.14 & 0.03 & 0.30 & 0.27 \\
\hline Transport & 0.12 & 0.11 & 0.00 & 0.23 & 0.18 \\
\hline Public services & 0.15 & 0.10 & 0.05 & 0.26 & 0.21 \\
\hline \multicolumn{6}{|l|}{ Location of employer } \\
\hline$>500,000:$ Tallinn & 0.13 & 0.12 & 0.01 & 0.25 & 0.25 \\
\hline 100, 000-500,000:Tartu & 0.14 & 0.11 & 0.02 & 0.25 & 0.23 \\
\hline Large towns: $50,000-99,000$ & 0.11 & 0.13 & -0.03 & 0.24 & 0.22 \\
\hline Other: small towns and rural areas & 0.12 & 0.12 & -0.01 & 0.24 & 0.23 \\
\hline \multicolumn{6}{|l|}{ Region } \\
\hline Northern Estonia & 0.14 & 0.13 & 0.01 & 0.27 & 0.24 \\
\hline Central Estonia & 0.10 & 0.12 & -0.02 & 0.22 & 0.20 \\
\hline North-Eastern Estonia & 0.11 & 0.12 & -0.01 & 0.23 & 0.17 \\
\hline Western Estonia & 0.12 & 0.13 & -0.01 & 0.24 & 0.22 \\
\hline Southern Estonia & 0.12 & 0.12 & 0.00 & 0.23 & 0.21 \\
\hline \multicolumn{6}{|l|}{ Ownership type } \\
\hline State & 0.11 & 0.14 & -0.03 & 0.25 & 0.22 \\
\hline Municipal firms & 0.02 & 0.13 & -0.11 & 0.16 & 0.05 \\
\hline Domestic private firms & 0.13 & 0.13 & 0.00 & 0.25 & 0.25 \\
\hline Foreign firms & 0.14 & 0.07 & 0.07 & 0.22 & 0.15 \\
\hline \multicolumn{6}{|l|}{ Firm's age, years } \\
\hline $0-1$ & 0.48 & 0.07 & 0.42 & 0.55 & 0.13 \\
\hline $2-4$ & 0.11 & 0.14 & -0.03 & 0.24 & 0.21 \\
\hline More than 5 & 0.06 & 0.13 & -0.06 & 0.19 & 0.13 \\
\hline
\end{tabular}

Note. The rates in the table are annual average job flows. When using averages, job flow rate definitions need not hold exactly, i.e. the difference between job creation and job destruction need not exactly equal the net employment change.

Source: Estonian Business Registry database, authors’ calculations 
Table 2. Job creation and destruction indicators by employer's size category

\begin{tabular}{|l|c|c|c|c|c|c|c|}
\hline Firm size class & $\begin{array}{c}\text { Share of job } \\
\text { creation }\end{array}$ & \multirow{2}{*}{$\begin{array}{c}\text { Share of job } \\
\text { destruction }\end{array}$} & \multirow{2}{*}{$\begin{array}{c}\text { Employment } \\
\text { share }\end{array}$} & \multicolumn{2}{|c|}{$\begin{array}{c}\text { Persistence of job } \\
\text { creation }\end{array}$} & \multicolumn{2}{|c|}{$\begin{array}{c}\text { Persistence of Job } \\
\text { destruction }\end{array}$} \\
\cline { 5 - 8 } & & & & One-year & Two-year & One-year & Two-year \\
\hline $1-9$ & 0.27 & 0.19 & 0.18 & 0.47 & 0.31 & 0.42 & 0.18 \\
\hline $10-19$ & 0.14 & 0.08 & 0.12 & 0.55 & 0.36 & 0.42 & 0.2 \\
\hline $50-49$ & 0.16 & 0.12 & 0.17 & 0.59 & 0.37 & 0.44 & 0.24 \\
\hline $100-249$ & 0.11 & 0.08 & 0.13 & 0.59 & 0.39 & 0.41 & 0.26 \\
\hline $250-499$ & 0.11 & 0.12 & 0.14 & 0.57 & 0.36 & 0.49 & 0.27 \\
\hline More than 500 & 0.07 & 0.04 & 0.08 & 0.62 & 0.29 & 0.44 & 0.25 \\
\hline
\end{tabular}

Source: Estonian Business Registry database, authors' calculations

We proceed to ask how job reallocation differs by sectors (industries) and what kind of changes have emerged over time with maturing of the transition. Jurajda and Terrell (2002a) found that in all industries in Estonia there is a higher level of job reallocation than in the Czech Republic, and they ascertained that job destruction in 1989-1995 was especially high in Estonian agriculture, but also in trade, which at the same time also enjoyed a very high level of job creation. In the more mature transitional period, the highest job destruction in Estonia is still in agriculture. There are high job destruction rates also in construction, trade and business services, but job creation in these industries is also very high. The level of excess job reallocation has been highest in sectors like business services, trade, and construction, but much lower in manufacturing and especially agriculture. These tendencies assure that transition leads to a convergence in the industrial structure of employment typical of mature market economies. In the theoretical (Aghion and Howitt, 1994) as well as empirical (Faggio and Konings, 2003) literature it is argued that higher turbulence or flexibility correlates with growth. Indeed, across the 37 STAN0 industries ${ }^{8}$, the correlation coefficient between excess and net rates is $0.26^{9}$. This

\footnotetext{
${ }^{8}$ See comment in footnote 6 , page 6 .

${ }^{9}$ We excluded four industries out of 41 with net employment change over $20 \%$. These are aircraft and spacecraft, railroad equipment and transport equipment, public administration and defence, compulsory
} 
could reflect Schumpeter's creative destruction process in which old unproductive units are replaced by new productive ones leading to higher growth.

Konings et al. (1996) analysed gross flows of jobs in Poland at the start of the transition and discovered high rates of gross job destruction concentrated in state-owned enterprises. They also found that new private firms contributed disproportionately to job growth in the economy. The same patterns apply to most other CEE countries as shown by Faggio and Konings (2003). There are striking differences in respect of gross job flows between state, municipal, domestic and foreign private firms in Estonia. As can be seen from Table 1, in the question of job creation, foreign firms are much more dynamic, leading to positive employment growth. Several researchers have shown that foreign direct investment (FDI) has played an important role in the development of the Estonian economy ${ }^{10}$. Mickievicz et al. (2000), and Varblane and Mickievicz (2001) have listed several factors characterising FDI influence on employment in the transition economies. They argue that FDI operates like a buffer either by generating new or maintaining the existing employment. They also support the idea that FDI can contribute to the domestic generation of employment and recovery rather than the view that FDI can lead to growth or generate the bulk of manufacturing employment.

Eamets et al. (2003a) found that the foreign-owned sector of Estonian manufacturing was less affected by the Russian crisis, determining that in the period 1998-99 the foreign-

social services, and post and telecommunications (according to STAN0 classification). See also Table A7 in Appendixes.

${ }^{10}$ According to Eamets et al. (2003b), Estonia has been successful in attracting foreign direct investment. The main state-owned large enterprises were sold by tenders in the form of large privatisation rounds, and a strong correlation exists between privatisation rounds and FDI inflow until 1996. Starting from that period, the structure of the FDI inflow changed. In 1997 and especially 1998, FDI inflows were in a larger part the result of the growth of reinvested earnings of foreign investors and acquisitions of Estonian privately owned firms and banks. During the Russian crisis in 1998 foreign investors, mainly Swedish and Finnish, used low share prices of firms reflecting difficulties in the Estonian economy and cheaply bought majorities in several Estonian firms. Starting from 2000, an important component of FDI is also reinvested earning from the stock of FDI and further acquisition of domestic capital owned firms by foreign investors. 
owned firms actually created jobs, while in the domestic firms in total almost 11,000 jobs were destroyed. Our analysis shows that jobs are destroyed in particular by municipal firms, but also by state-owned ones. We also observe more heterogeneity in the employment behaviour of state and domestic private firms as shown by the high excess job reallocation rate. Studying workers' displacement in Estonia, Lehmann et al. (2002) found that the magnitudes and direction of displaced workers lend support to a model of labour reallocation from the state to the private sector. In $1992,77 \%$ of all displaced workers came from the state sector and this percentage fell to $17 \%$ in 1998 .

We analysed two dimensions of job dynamics in the regions: first, the size of settlement (large towns, small towns, rural areas), and then regional aspect (according to EU NUTS3 division Estonia has five geographical regions). There was not much variation in the first dimension, except that net change was positive in Tallinn and negative in large towns (including also North-East Estonia) and rural areas, reflecting the reallocation of labour to large centres. In the second dimension, the labour market flexibility is highest in Northern Estonia (excess reallocation of 24\%) and lowest in North-Eastern Estonia (17\%) - the former is the capital region, while the latter has the most difficult economic situation in Estonia due to both the hardships in adapting the large-scale heavy industry to market economy and the language problems of the non-Estonian population.

The last section of Table 1 analyses the job flows rates by the firms' age. Our age measure depicts the year when the firm was registered in the business registry. In case the year of entry (the year when the firm for the first time experienced positive sales or a positive number of employees) was different, we used this. By theory (see e.g. Jovanovics, 1982) new firms face uncertainty about the cost of production and demand for products. Over time, as such information is accumulated, unprofitable plants exit and profitable plants 
survive and settle down to more stable employment levels. The net job creation rate declined with the firm's age. This could reflect replacement of old firms with new ones having technological and organisational advantages. The gross reallocation declines also with the firm's age, but not with the excess job reallocation rate (as indicated by Davis et al. 1997). This is due to the rapid employment growth among the newly established firms (as compared to older firms), i.e. the volatility of employment growth becomes important only at the age of 2-4 years.

\subsection{Decomposition of excess job reallocation}

We next turn to the possible reasons for the very high job flows in Estonia. One explanation could be that Estonia has been a rapidly reforming economy, with a rapid labour reallocation (high worker flows) that has changed the employment structure within a comparatively short time (Eamets 2003). For example, if we take flows from unemployment to employment, then the transition rate dropped from $44 \%$ in 1994 to $28 \%$ in 2000. Though this factor is still important, its importance has declined.

The numbers in Table 3 show that the fraction of excess job reallocation due to shifts between industries varies from $11 \%$ to $19 \%$. It is a common finding in the literature that firms' performance and job flows are very heterogeneous even within narrowly defined industries and determined by idiosyncratic factors. The reasons for heterogeneity were already explained in the introductory section. 
Table 3. Fraction of excess job reallocation resulting from employment shifts between different groups

\begin{tabular}{|l|r|r|r|r|r|r|}
\hline Group & $\mathbf{1 9 9 6}$ & $\mathbf{1 9 9 7}$ & $\mathbf{1 9 9 8}$ & $\mathbf{1 9 9 9}$ & $\mathbf{2 0 0 0}$ & Average \\
\hline Location & 0.09 & 0.02 & 0.06 & 0.00 & 0.03 & 0.04 \\
\hline Regions, NUTS3 & 0.13 & 0.02 & 0.07 & 0.01 & 0.01 & 0.05 \\
\hline Industry, STAN0 & 0.13 & 0.11 & 0.27 & 0.18 & 0.19 & 0.18 \\
\hline Size class & 0.11 & 0.12 & 0.14 & 0.06 & 0.11 & 0.11 \\
\hline Ownership type & 0.02 & 0.02 & 0.09 & 0.07 & 0.08 & 0.06 \\
\hline
\end{tabular}

Source: Estonian Business Registry database, authors' calculations

However, in our data the proportion of excess reallocation due to inter-industry shifts is still extremely high compared to the studies of western countries (Baldwin et al. 1998 report excess reallocation for Canada to equal $2.5 \%$ and for the USA 3.6\%). Faggio and Konings (2003) report the average of 1994-97 in Estonia to be even higher, 28\%, which could be at least partly explained by the size threshold in their data and the smallness of their sample (only about 233 firms), so that there was only a limited number of firms in each group causing the between-group shifts to be relatively important. The shifts across size classes are also relatively important in Estonia (11\% of excess reallocation), while the shifts across ownership type are relatively low $-6 \%$ of excess reallocation. Decompositions for regions show that ca $5 \%$ of excess reallocation is due to shifts between regions. We conclude that changes in the structure of the economy have remarkably shaped the job destruction and creation process.

\subsection{Institutional framework and firm dynamics in Estonia}

It seems that at least to some extent institutions and business environment matter for firmlevel dynamics and productivity growth. According to the concept of labour market flexibility used by Eamets et al. (2003b), institutional aspects of flexibility such as labour 
legislation, labour policy, and trade unions affect the micro-level flexibility, which involves workers and job flows. In general, we can expect that countries with less institutional intervention also have a more flexible labour market in terms of higher labour market mobility (both job and worker flows). A good example is the US labour market compared with the EU labour markets, for example, Portugal (see also Blanchard and Portugal, 2001). However, Addison and Teixeira (2001) report the surprising finding that the annual rates of job reallocation are often equally high in nations with stringent job protection and countries with weak regulations. There are several explanations to it. First, stricter employment protection legislation leads to a higher proportion of short-term jobs whose holders compete with unemployed persons and thereby reduce their job-finding possibilities and job turnover. In less regulated markets there are higher unemployment flows and in more regulated markets more job-to-job flows. Second, if strict employment protection coincides with rigidities in the wage setting, adjustment to adverse shocks occurs with employer-initiated job turnover. Third, the inter-country differences in quarterly data need not show up in annual data. Finally, job turnover could be countercyclical in unregulated labour markets while pro-cyclical in regulated labour markets (Garibaldi, 1998), which may impact on the cross-country relationship between strictness of labour laws and job flows. This verifies that at least to some extent institutions matter for firm-level dynamics.

Acquisti and Lehmann (2000) found evidence for Russia that new firms have disproportionately high job creation and destruction rates. They argue that the latter might be attributed to a relatively hostile environment for new businesses in Russia and the managers' lack of experience to operate in this environment. This motivates the question about whether the high firm dynamics in Estonia have been due to the favourable regulation of business activity. Estonian legal environment is transparent and open to 
foreign investment. A number of laws governing the business environment were enacted very early in Estonia's transition (Bankruptcy Law 1992, Law on Competition 1993).

Table 4 summarises some of the available data on how easy it is to establish a firm and change employment in Estonia. In Estonia, starting a new business involves relatively small administrative burdens; the potential entrepreneur needs a relatively small number of permits and time to start a firm: creation of firms is rather common. In fact, according to some indicators, Estonia ranks at very high positions among the surveyed countries and the ease of starting a firm has significantly contributed to the overall high estimates of economic freedom.

The only area where notable regulations exist is employment protection. From a formal point of view, the legal regulation of the labour market seems to be in place and workers are even better protected in Estonia than in the EU. But in practice it appears that the state regulations are not always followed in the private sector. In one of our earlier papers (see Eamets and Masso, 2003) we found ample evidence of violations of these regulations in Baltic enterprises. Workers' complaints to labour inspectors are rather frequent and in labour disputes employees' often lodge appeals, which may indicate that law enforcement is weak. But the problem is that appeals may represent only a small number of all breaches of law. 
Table 4. Administrative regulations affecting firms' entry and exit in Estonia and other countries

\begin{tabular}{|c|c|c|c|c|c|c|c|c|c|c|c|c|}
\hline & \multicolumn{2}{|c|}{$\begin{array}{c}\text { Entry into local } \\
\text { markets }{ }^{\text {a }}\end{array}$} & \multicolumn{2}{|c|}{$\begin{array}{c}\text { Administrative } \\
\text { burden for a } \\
\text { start-Up }\end{array}$} & \multicolumn{2}{|c|}{$\begin{array}{c}\text { Permits to start } \\
\text { a firm }\end{array}$} & \multicolumn{2}{|c|}{$\begin{array}{c}\text { Days to start a } \\
\text { firm }\end{array}$} & \multicolumn{2}{|c|}{$\begin{array}{c}\text { Creation of } \\
\text { firms is unusual } \\
/ \text { is common in } \\
\text { the country }\end{array}$} & \multicolumn{2}{|c|}{$\begin{array}{c}\text { Employment } \\
\text { protection } \\
\text { regulations }\end{array}$} \\
\hline & Value & Rank $^{\mathrm{d}}$ & Value & Rank $^{\mathrm{d}}$ & Value & Rank $^{\mathrm{d}}$ & Value & $\operatorname{Rank}^{\mathrm{d}}$ & Value & Rank $^{\mathrm{e}}$ & Value & $\operatorname{Rank}^{\mathrm{f}}$ \\
\hline Estonia & 5.6 & 12.0 & 5.8 & 5.0 & 3.0 & 5.0 & 30.0 & 34.0 & 8.2 & 4.0 & 2.1 & 14.0 \\
\hline EU average & 5.5 & 23.6 & 4.8 & 27.3 & 4.8 & 26.8 & 41.4 & 38.2 & 6.6 & 29.2 & 2.5 & 15.9 \\
\hline $\begin{array}{l}\text { OECD } \\
\text { average }\end{array}$ & 5.4 & 27.5 & 4.8 & 28.8 & 4.8 & 27.2 & 38.3 & 36.8 & 6.8 & 26.3 & 2.2 & 19.4 \\
\hline CEE average & 5.3 & 30.7 & 4.2 & 43.8 & 4.7 & 31.9 & 33.2 & 36.7 & 7.3 & 17.0 & 2.6 & 14.5 \\
\hline
\end{tabular}

Source: Global Competitiveness Report 2001-2002; World Competitiveness Yearbook 2001; Riboud et al. 2001

Notes: ${ }^{\mathrm{a}}$ - how often the entry of new competitors occurs in the local market, 1 to $7 ;^{\mathrm{b}}$ - from 1 (starting a new business is not difficult) to 7 (starting a new business is difficult); ${ }^{c}$ - Employment Protection Index (EPI) varies from 0 (unrestrictive) to 6 (restrictive); ${ }^{\mathrm{d}}$ - rank among 75 countries; ${ }^{\mathrm{e}}$ - rank among 49 countries; ${ }^{\mathrm{f}}$ Rank among 34 countries

Secondly, it is important for employment protection legislation strictness what proportion of the workforce is actually covered by the regulations. In the Baltic States, we found, the share of workers on unlimited contracts is close to the EU level, but temporary employment is more widespread (implying a higher level of flexibility). The positive correlation between the share of temporary employment and the strictness of the respective legislation in the Baltic countries may reflect their poor enforcement of legislation.

Regarding policy suggestions, we argue that loosening of employment protection laws could be discussed; besides increasing economic efficiency it should also be socially more acceptable from now on, because after the introduction of the unemployment insurance system in Estonia (in 2002) protection against the risk of unemployment has increased. 


\section{Conclusions and implications}

Our results show that job creation and destruction rates in Estonia are very high in international comparison, higher than in any other European country, and comparable to the levels documented for the United States. We estimate the amount of job flows over and above the amount needed to accommodate net employment changes to be about $23 \%$ per year - higher than has been found in any other European country so far. Average excess rate of labour allocation was $18 \%$ in the US, $9 \%$ in the UK and only $6 \%$ in Germany. It suggests that the Estonian economic development is a good example of the success story of economic shock therapy. As a result, relatively fast restructuring was accompanied by high labour reallocation. The high flexibility in terms of job flows can be largely ascribed to the small firms sector; the estimates of job flows in previous studies are biased downwards. Compared with studies of the western countries, a very high proportion of labour reallocation is explained by shifts between industries reflecting rapid changes in the economic structure.

To some extent, this phenomenon is typical of a transition process, but not only. Although by the dynamics of the other labour market characteristics it seems that the restructuring of the labour market was over by 2001: the worker flows between labour market states dropped significantly, but at the same time the aggregate job flows did not diminished. In our opinion, there are essentially four reasons for that.

Firstly, the inter-sectoral mobility has been relatively high: the shares of different sectors in employment have changed considerably and much of the excess job reallocation is due

to shifts between the sectors. We found that a rather high fraction of excess job reallocation (18\% on average for 1996-2000) is explained by sectoral shifts. 
Secondly, small firms seem to play a key role in labour reallocation. Small firms with less than 20 employees employ one fourth of the labour force. The net rate of labour allocation is positive, which means they create more jobs than close. Also the excess rate seems to be particularly high in firms with less than 10 employees (36\%).

Thirdly, the occupational mobility of the workforce in Estonia is high. This was not analysed in our paper, but Campos and Dabušinskas (2003) documented that between 35 and $50 \%$ of all Estonian wage earners changed occupation in 1989-1995; however, most of these changes took place at the beginning of the transition, so the impact of occupational changes on job mobility may have declined by now. As the reallocation process affects certain industries and enterprises more than others, the role of personal characteristics in the incidence of displacement is insignificant. However, many people have changed their occupation over the transition period. In our understanding, this indicates rather good quality of human capital in Estonia. In this respect, a possible problem is the rather low financing of active labour market programmes in Estonia.

Finally, the Estonian institutional environment has been rather favourable for firm dynamics: starting a new firm has been fairly inexpensive.

The main research question of the paper is still unsolved. Why have worker flows declined while job flows are still high and stable? One possible explanation that would need further confirmation by data processing is the possibility that the majority of worker flows were due to high flows inside the firm (occupational mobility). Such flow activities have declined and inter-firms workers mobility has been relatively stable. To get answers to this question we need to proceed with the decomposition of worker flows and investigate the types of worker flows (within the firm and inter-firms) separately. 
The message of the paper in terms of policy implications could be that the flexible enterprise environment should be maintained in Estonia. This suggestion is supported by the theoretical and empirical evidence of the positive impact of higher flexibility and dynamics on growth. 


\section{References}

Addison, J. T. and P. Teixeira (2001), "The Economics of Employment Protection", IZA

Discussion Paper, No. 381, 63 pp.

Aghion, P. and P. Howitt (1994), "Growth and Unemployment", Review of Economic Studies, Vol. 61, No. 3, pp. 477-494.

Ahn, S. (2001), "Firm dynamics and productivity growth: a review of micro evidence from OECD countries”, OECD Economics Department Working Paper, No. 297, Paris.

Baldwin, J., Dunne, T. and J. Haltiwanger (1998), “A Comparison of Job Creation and Job Destruction in Canada and the United States", The Review of Economics and Statistics, Vol. 80, No. 3, pp. 347-356.

Bartelsman, E. and M. Barnes (2001), "Comparative Analysis of Firm Level Data: A Low Marginal Cost Approach”, OECD DSTI/EAS/IND/SWP/AH(2001)

Bartelsman, E., Scarpetta, S. and F. Schivardi (2003), "Comparative Analysis of Firm Demographics and Survival: Micro-Level Evidence for the OECD countries", OECD Economics Department Working Paper, No. 348, 59 pp.

Basu, S., Estrin, S. and J. Svejnar (1997), "Employment and wage behaviour of industrial enterprises in transition economies: The cases of Poland and Czechoslovakia", Economics of Transition, Vol. 5, No. 2, pp. 271-287.

Blanchard, O., and P. Portugal (2001) 'What Hides Behind an Unemployment Rate: Comparing Portuguese and U.S. Labour Markets', American Economic Review, Vol 91, No 1, March 2001, pp 187-207 
Brown, J.D. and J. S. Earle (2002), “Gross Job Flows in Russian Industry Before and After Reform: Has Destruction Become More Creative?", Journal of Comparative Economics, Vol. 30, pp. 96-133.

Caballero, R. J. and M. L. Hammour (1996), “On the Ills of Adjustment”, Journal of Development Economics, No 51, pp. 161-192.

Campos, N. F. and A. Dabušinskas (2003), "So Many Rocket Scientists, So Few Marketing Clerks: Occupational Mobility in Times of Rapid Technological Change", William Davidson Institute Working Paper No 552, 28 pp.

Davis S.J. and J. C. Haltiwanger (1999), "Gross Job Flows", in Ashenfelter, O. and D. Card, (Ed.), Handbook of Labour Economics, Vol. 3, Elsevier, pp. 2711-2805.

Davis, S. J. and J. C. Haltiwanger (1992), “Gross job creation, gross job destruction and employment reallocation”, Quarterly Journal of Economics, Vol. 107, No. 3, pp. 819-863.

Davis, S. J., Haltiwanger, J. C. and S. Schuh (1997), “Job creation and job destruction”. The MIT Press, Cambridge (Massaschusetts), London (England), 260 pp.

Eamets, R. (2003), “Tööturuliikumiste analüüs piirkonniti”, in H. Kaldaru (Ed.), Eesti Regionaalarengu sotsiaalmajanduslik käsitlus, 1k. 183-235. Tartu: Tartu Ülikooli Kirjastus.

Eamets, R. and J. Masso (2003), “Labour Market Flexibility and Employment Protection Regulation in the Baltic States", Tallinn Technical University Working Papers in Economics, No. 03/91-03/103, pp. 49-82.

Eamets, R., Kallaste, E., Masso, J. and M. Rõõm (2003a), "How flexible are labour markets in the CEECs? A macro level approach", TRANSFER (Quarterly of the European Trade Union Institute), Vol. 9, No. 1, pp. 101-121. 
Eamets, R., Varblane U. and K. Sõstra (2003b), “External Macroeconomic Shocks and the Estonian Economy: How did the Russian Financial Crisis affect Estonian Unemployment and Foreign Trade?", Baltic Journal of Economics, Vol. 3, No. 2, pp. 5-24.

Ericson, R. and A. Pakes (1995), "Markov perfect industry dynamics: a framework for empirical analysis", Review of Economic Studies, Vol. 63, No. 1, pp. 53-82.

Estrin S., and J. Svejnar (1998), "The Effects of Output, Ownership and Legal form on Employment and Wages on Central European Firms". In S. Commander (ed.), Enterprise Restructuring and Unemployment in Models of Transition, Washington DC: EDI/World Bank.

Faggio, G. and J. Konings (2003), "Job creation, job destruction and employment growth in transition countries in the 90s", Economic Systems, Vol. 27, pp. 129-154.

Garibaldi, P. (1998), “Job Flow Dynamics and Firing Restrictions”, European Economic Review, Vol. 42, pp. 245-275.

Haltiwanger, J. C. and M. Vodopivec (2002), "Gross worker and job flows in a transition economy: an analysis of Estonia”, Labour Economics, Vol. 9, pp. 601-630.

Haltiwanger, J., Lehmann, H. and K. Terrell (2003), "Job Creation and Job Destruction in Transition Countries”, Economics of Transition, Vol. 11, No. 2, pp. 205-219.

Jovanovic, B. (1982), "Selection and the Evolution of an Industry", Econometrica, Vol. 50, No. 3, pp. 649-670.

Jurajda, Š. and K. Terrell (2002a), "Job Growth in Early Transition: Comparing Two Paths", IZA Discussion Paper, No. 589, 37 pp. 
Jurajda, Š. and K. Terrell (2002b), "What drives the Speed of Job Reallocation during Episodes of Massive Adjustment?”, IZA Discussion Paper, No. 601, 46 pp.

Konings, J., Kupets, O. and H. Lehmann (2002), “Gross Job Flows in Ukraine: Size, Ownership and Trade Effects”, IZA Discussion Paper, No. 675, 59 pp.

Konings, J., Lehmann, H. and M. Schaffer (1996), “Employment Growth, Job Creation and Job Destruction in Polish Industry: 1988-91”, Labour Economics, Vol. 3, pp. 299-317.

Lehmann, H., Philips, K. and J. Wadsworth (2002), “The Incidence and Cost of Job Loss in a Transition Economy: Displaced Workers in Estonia, 1989-1999”, IZA Discussion Paper, No. 567, 51 pp.

Mickievicz, T., Radosevic, S. and U. Varblane (2000), "Foreign Direct Investment, Structures of Employment and Job Creation in Transition Economies (1993-1996)", In Foreign Direct Investment in Transition Economy, London, UCL Press, pp. 41-60.

Scarpetta, S., Hemmings, P., Tressel, T., and J. Woo (2002), “The role of policy and institutions for productivity and firm dynamics: evidence from micro and industry data", OECD Economics Department Working Paper, No. 329.

Varblane, U. and T. Mickievicz (2001), "FDI in Central Europe: Short-Run Effects in Manufacturing", in Farby, N., Zeghani, S., Kogut, B (eds.) Transition in Asia and Eastern and Central Europe: A Closed Door and Two Open Windows?, Nova Science Publishers, New York, pp. 31-54.

Venesaar, U. (2003), “Töökohtade loomine ja kaotamine Eesti ettevõtetes”, In Ettevõttemajandus Eestis ja Euroopa Liit, Mattimar, Tallinn, Pärnu, pp. 236-244. 
Vodopivec, M. (2003), "Data on Job Flows in Estonia for 1989-1999 based on Estonian Labour Force Survey Data”, personal communication. 


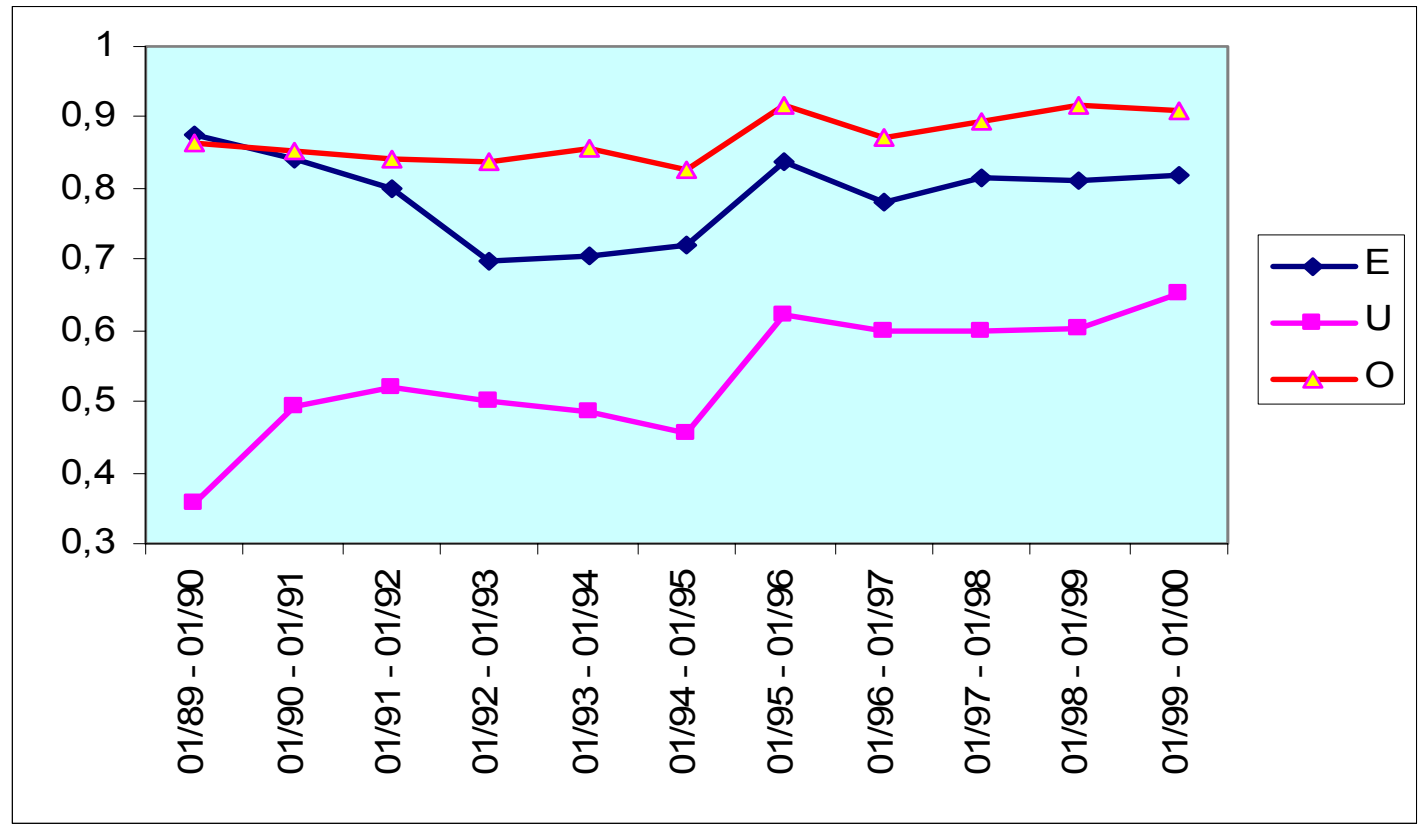

Figure A1. Worker flows dynamics: stable states

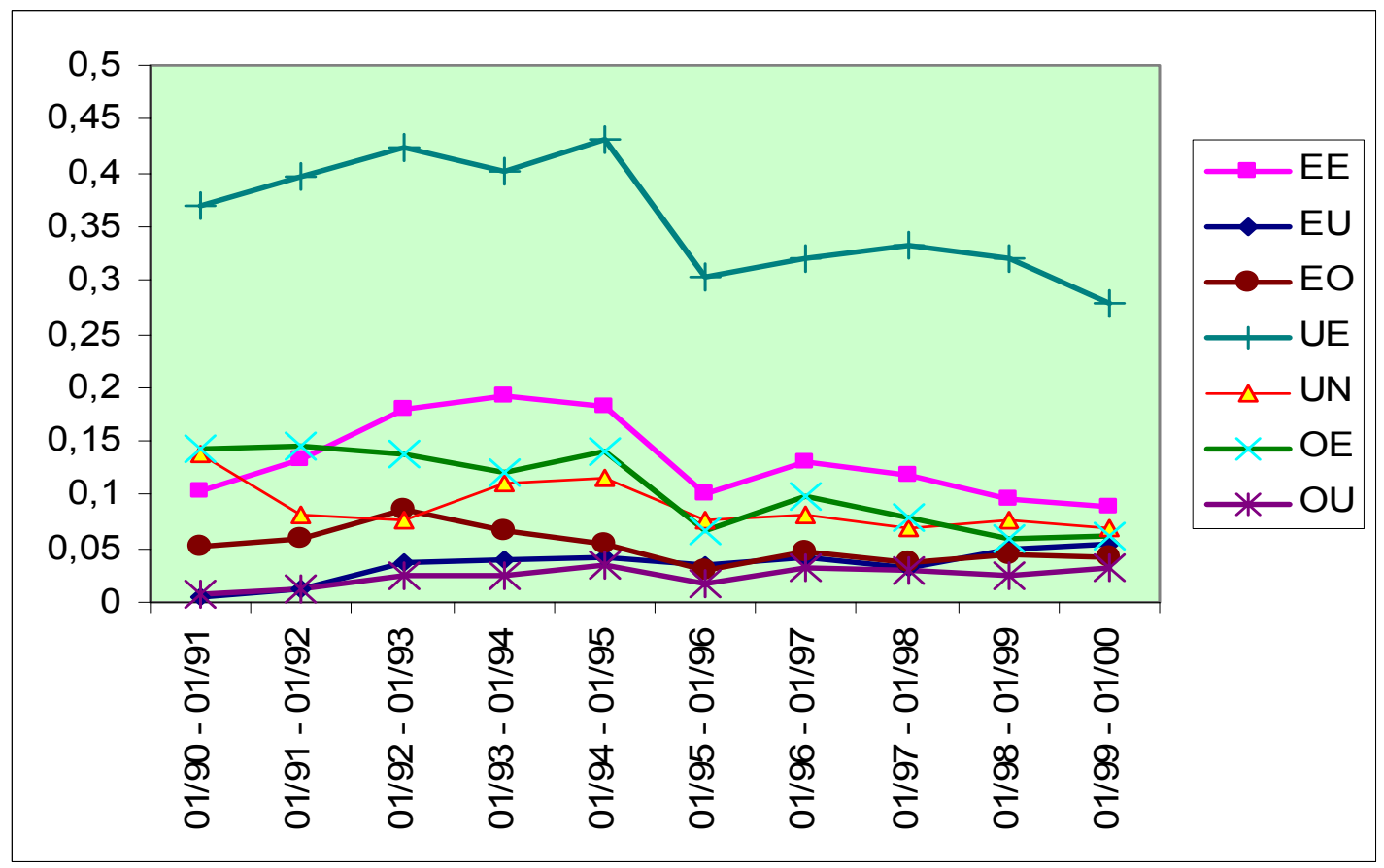

Figure A2. Worker flows dynamics: flows between labour market states 


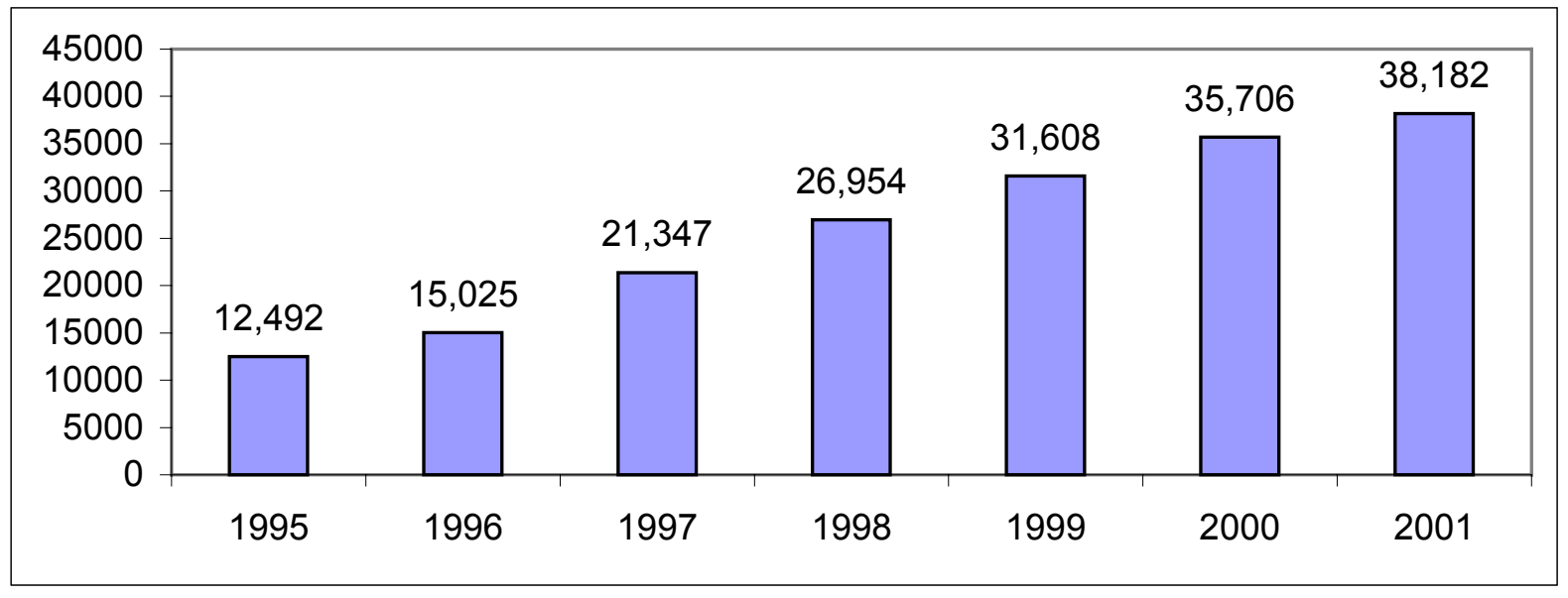

Figure A3. The evolution of the total number of firms in the Estonian Business

\section{Registry data}

Source: Estonian Business Registry database, authors' calculations

Table A1. Distribution of observations across employers' size classes (all years)

\begin{tabular}{|c|c|c|c|c|c|c|}
\hline Size class & $\begin{array}{c}\text { Number of } \\
\text { employees }\end{array}$ & Frequency & Percentage & $\begin{array}{c}\text { Cumulative } \\
\text { percentage }\end{array}$ & $\begin{array}{c}\text { Employment } \\
\text { share }\end{array}$ & $\begin{array}{c}\text { Cumulative } \\
\text { employment } \\
\text { share }\end{array}$ \\
\hline 1 & 0 & 53,529 & 23.35 & 23.35 & 0.00 & 0.00 \\
\hline 2 & $1-9$ & 74,030 & 32.29 & 55.64 & 13.43 & 13.43 \\
\hline 3 & $10-19$ & 17,697 & 7.72 & 63.36 & 11.28 & 24.71 \\
\hline 4 & $20-49$ & 12,217 & 5.33 & 68.68 & 17.33 & 42.04 \\
\hline 5 & $50-99$ & 4,325 & 1.89 & 70.57 & 13.96 & 56.00 \\
\hline 6 & $100-249$ & 2,067 & 0.90 & 71.47 & 14.60 & 70.60 \\
\hline 7 & $250-449$ & 585 & 0.26 & 71.73 & 9.58 & 80.18 \\
\hline 8 & More than 500 & 316 & 0.14 & 71.86 & 19.82 & 100.00 \\
\hline 9 & Not available & 64,506 & 28.14 & 100 & 0.00 & 100.00 \\
\hline
\end{tabular}


Source: Estonian Business Registry database, authors' calculations 
Table A2. Distribution of firms across industries

\begin{tabular}{|l|c|c|}
\hline Industry & Frequency & Percent \\
\hline Agriculture, hunting and forestry & 2,586 & 4.98 \\
\hline Fishing & 1 & 0 \\
\hline Mining and quarrying & 6,870 & 0.25 \\
\hline Manufacturing & 394 & 13.23 \\
\hline Electricity, gas and water supply & 3,561 & 0.76 \\
\hline Construction & 18,660 & 6.86 \\
\hline Wholesale and retail trade; repair of motor vehicles, & & 35.92 \\
motorcycles and personal and household goods & 2,104 & 4.05 \\
\hline Hotels and restaurants & 3,874 & 7.46 \\
\hline Transport, storage and communication & 795 & 1.53 \\
\hline Financial intermediation & 10,180 & 19.6 \\
\hline Real estate, renting and business activities & 4 & 0.01 \\
\hline Public administration and defence; compulsory social security & 520 & 1 \\
\hline Education & 656 & 1.26 \\
\hline Health and social work & 1,607 & 3.09 \\
\hline Other community, social and personal service activities & 1 & 0 \\
\hline Private households with employed persons & 1 & 0 \\
\hline Extra-territorial organisations and bodies & 51,944 & 100 \\
\hline Total economy & & \\
\hline
\end{tabular}

Source: Estonian Business Registry database, authors' calculations

\section{Table A3. Distribution of observations across regions}

\begin{tabular}{|c|l|l|r|c|}
\hline Number & \multicolumn{1}{|c|}{ Region } & \multicolumn{1}{|c|}{ The definition of region } & Frequency & Percent \\
\hline 1 & Northern Estonia & Tallinn and Harju county & 114,663 & 50.0 \\
\hline 2 & Central Estonia & Järva, Lääne-Viru and Rapla counties & 15,938 & 7.0 \\
\hline 3 & North-Eastern Estonia & Ida-Viru county & 13,339 & 5.8 \\
\hline 4 & Western Estonia & Hiiu, Lääne, Pärnu and Saare counties & 2,470 & 11.1 \\
\hline 5 & Southern Estonia & $\begin{array}{l}\text { Jõgeva, Põlva, Tartu, Valga, Viljandi and } \\
\text { Võru counties }\end{array}$ & 59,854 & 26.1 \\
\hline 6 & Missing value & & 8 & 0.0 \\
\hline Total & & & $\mathbf{2 2 9 , 2 7 2}$ & $\mathbf{1 0 0 . 0}$ \\
\hline
\end{tabular}

Source: Estonian Business Registry database, authors' calculations 
Table A4. Distribution of observations by firm ownership groups and years (the number of firms and the relative frequency in a given year in per cents)

\begin{tabular}{|l|c|c|c|c|c|c|c|}
\hline Ownership form & $\mathbf{1 9 9 5}$ & $\mathbf{1 9 9 6}$ & $\mathbf{1 9 9 7}$ & $\mathbf{1 9 9 8}$ & $\mathbf{1 9 9 9}$ & $\mathbf{2 0 0 0}$ & $\mathbf{2 0 0 1}$ \\
\hline State & 198 & 145 & 107 & 82 & 53 & 52 & 49 \\
\hline Municipal firms & $2.0 \%$ & $1.0 \%$ & $1.0 \%$ & $0.0 \%$ & $0.0 \%$ & $0.0 \%$ & $0.0 \%$ \\
\hline & 315 & 267 & 209 & 266 & 287 & 268 & 252 \\
\hline Domestic private firms & $3.0 \%$ & $2.0 \%$ & $1.0 \%$ & $1.0 \%$ & $1.0 \%$ & $1.0 \%$ & $1.0 \%$ \\
\hline & $89.0 \%$ & $90.0 \%$ & $92.0 \%$ & $90.0 \%$ & $85.0 \%$ & $77.0 \%$ & $82.0 \%$ \\
\hline Foreign firms & 835 & 1030 & 1079 & 1907 & 1940 & 2347 & 2575 \\
\hline & $7.0 \%$ & $7.0 \%$ & $5.0 \%$ & $7.0 \%$ & $6.0 \%$ & $7.0 \%$ & $7.0 \%$ \\
\hline Public institutions & & & & & & 2 & 1 \\
\hline & & & & & & $0.0 \%$ & $0.0 \%$ \\
\hline Other & 41 & 30 & 20 & 1 & 3 & 1 & 1 \\
\hline & $0.0 \%$ & $0.0 \%$ & $0.0 \%$ & $0.0 \%$ & $0.0 \%$ & $0.0 \%$ & $0.0 \%$ \\
\hline Missing & 15 & 48 & 189 & 503 & 2448 & 5452 & 3823 \\
\hline & $0.0 \%$ & $0.0 \%$ & $1.0 \%$ & $2.0 \%$ & $8.0 \%$ & $15.0 \%$ & $10.0 \%$ \\
\hline Total & 12492 & 15025 & 21346 & 26954 & 31068 & 35706 & 38182 \\
\hline
\end{tabular}

Source: Estonian Business Registry database, authors' calculations

Table A5. The number of different kinds of transactions in the Business Registry data

\begin{tabular}{|c|c|c|c|c|c|}
\hline Transaction & Description & Frequency & Percent & $\begin{array}{c}\text { The average } \\
\text { proportion of firms } \\
\text { involved weighted by } \\
\text { employment }\end{array}$ & $\begin{array}{l}\text { The average } \\
\text { proportion of } \\
\text { firms involved }\end{array}$ \\
\hline Predecessor & Change in firm id & 24,418 & 97.53 & 0.695 & 0.493 \\
\hline Acquisition & $\begin{array}{l}2 \text { or more firms } \\
\text { merge, no new id }\end{array}$ & 366 & 1.46 & 0.039 & 0.005 \\
\hline Merger & $\begin{array}{l}2 \text { or more firms } \\
\text { merge, old firms } \\
\text { terminate and new } \\
\text { firm is formed }\end{array}$ & 191 & 0.76 & 0.022 & 0.002 \\
\hline Break up & $\begin{array}{l}\text { A firm is divided } \\
\text { in } 2 \text { or more } \\
\text { pieces, old firm is } \\
\text { terminated }\end{array}$ & 17 & 0.07 & 0.001 & 0.000 \\
\hline Divestiture & $\begin{array}{l}2 \text { or more units } \\
\text { separate, old firm } \\
\text { continues }\end{array}$ & 39 & 0.16 & 0.010 & 0.001 \\
\hline $\begin{array}{l}\text { Unofficial } \\
\text { predecessor }\end{array}$ & & 5 & 0.02 & 0.000 & 0.000 \\
\hline No transaction & & - & - & 0.234 & 0.500 \\
\hline Total & & 25,036 & 100.00 & 100.00 & 100.00 \\
\hline
\end{tabular}

Source: Estonian Business Registry database, authors' calculations 
Table A6. Firm size across industries and time

\begin{tabular}{|c|c|c|c|c|c|}
\hline STAN & Year & Mean employment & $\begin{array}{c}\text { Standard deviation } \\
\text { of employment }\end{array}$ & $\begin{array}{l}\text { Coefficient of } \\
\text { variation }\end{array}$ & $\begin{array}{c}\text { Share of industry } \\
\text { employment in } \\
\text { total employment }\end{array}$ \\
\hline \multirow[t]{7}{*}{ Manufacturing } & 1995 & 37.6 & 141.1 & 3.8 & $33 \%$ \\
\hline & 1996 & 42.0 & 139.9 & 3.3 & $33 \%$ \\
\hline & 1997 & 44.1 & 139.1 & 3.2 & $32 \%$ \\
\hline & 1998 & 40.0 & 121.7 & 3.0 & $31 \%$ \\
\hline & 1999 & 35.8 & 105.5 & 2.9 & $31 \%$ \\
\hline & 2000 & 34.5 & 107.9 & 3.1 & $32 \%$ \\
\hline & 2001 & 32.6 & 125.7 & 3.9 & $32 \%$ \\
\hline \multirow[t]{7}{*}{ Agriculture } & 1995 & 23.4 & 37.5 & 1.6 & $9 \%$ \\
\hline & 1996 & 30.5 & 74.7 & 2.5 & $10 \%$ \\
\hline & 1997 & 29.8 & 76.0 & 2.5 & $8 \%$ \\
\hline & 1998 & 26.0 & 72.9 & 2.8 & $7 \%$ \\
\hline & 1999 & 20.1 & 40.3 & 2.0 & $6 \%$ \\
\hline & 2000 & 16.8 & 36.8 & 2.2 & $5 \%$ \\
\hline & 2001 & 16.2 & 36.7 & 2.3 & $5 \%$ \\
\hline \multirow[t]{7}{*}{ Services } & 1995 & 13.3 & 66.9 & 5.0 & $44 \%$ \\
\hline & 1996 & 14.4 & 69.7 & 4.8 & $45 \%$ \\
\hline & 1997 & 15.1 & 94.2 & 6.3 & $43 \%$ \\
\hline & 1998 & 14.0 & 87.3 & 6.2 & $45 \%$ \\
\hline & 1999 & 12.9 & 77.4 & 6.0 & $47 \%$ \\
\hline & 2000 & 11.7 & 66.5 & 5.7 & $48 \%$ \\
\hline & 2001 & 10.8 & 59.4 & 5.5 & $49 \%$ \\
\hline \multirow[t]{7}{*}{ Total economy } & 1995 & 19.4 & 82.8 & 4.3 & $100 \%$ \\
\hline & 1996 & 21.0 & 84.7 & 4.0 & $100 \%$ \\
\hline & 1997 & 23.4 & 139.5 & 6.0 & $100 \%$ \\
\hline & 1998 & 21.1 & 130.9 & 6.2 & $100 \%$ \\
\hline & 1999 & 18.9 & 108.9 & 5.8 & $100 \%$ \\
\hline & 2000 & 16.9 & 89.8 & 5.3 & $100 \%$ \\
\hline & 2001 & 15.6 & 85.8 & 5.5 & $100 \%$ \\
\hline
\end{tabular}

Source: Estonian Business Registry database, authors' calculations 
Table A7. Average firm size in Estonia and in OECD countries

\begin{tabular}{|c|c|c|c|c|c|}
\hline \multirow{2}{*}{$\begin{array}{l}\text { Industry: } \\
\text { ST AN code }\end{array}$} & \multirow{2}{*}{ Industry: description } & \multicolumn{2}{|c|}{ Mean employment } & \multicolumn{2}{|c|}{$\begin{array}{c}\text { Standard deviation of } \\
\text { employment }\end{array}$} \\
\hline & & Estonia & OECD average & Estonia & OECD average \\
\hline $1 \mathrm{t} 5$ & Agriculture & 23.3 & 5.5 & 53.6 & 67.26 \\
\hline $10 \mathrm{t} 4$ & Mining and quarrying & 175.0 & 35.8 & 770.6 & 152.31 \\
\hline $15 \mathrm{t} 37$ & Total manufacturing & 38.1 & 40.8 & 125.8 & 350.77 \\
\hline $15 \mathrm{a} 6$ & Food products & 58.4 & 41.0 & 137.4 & 510.92 \\
\hline $17 \mathrm{t} 9$ & Textiles & 49.4 & 33.5 & 140.9 & 160.06 \\
\hline 20 & Wood products & 21.4 & 15.5 & 46.6 & 47.34 \\
\hline $21 \mathrm{a} 2$ & Pulp and paper & 19.8 & 33.4 & 45.4 & 176.47 \\
\hline 24 & Chemicals & 62.6 & 82.4 & 165.4 & 416.03 \\
\hline 26 & $\begin{array}{l}\text { Other non-metallic mineral } \\
\text { products }\end{array}$ & 41.9 & 30.3 & 77.6 & 158.53 \\
\hline $27 \mathrm{t} 33$ & Basic metals and machinery & 30.2 & 39.4 & 114.4 & 258.81 \\
\hline $34 \mathrm{a} 5$ & Transport equipment & 80.9 & 228.4 & 208.7 & 1525.91 \\
\hline $36 \mathrm{a} 7$ & Furniture, recycling & 44.1 & 20.3 & 144.4 & 105.25 \\
\hline $40 \mathrm{a} 1$ & $\begin{array}{l}\text { Electricity, gas and water } \\
\text { supply }\end{array}$ & 51.0 & 97.1 & 275.4 & 1388.76 \\
\hline 45 & Construction & 19.3 & 9.8 & 36.9 & 195.34 \\
\hline $50 \mathrm{t} 74$ & Business sector services & 13.1 & 16.3 & 77.2 & 382.19 \\
\hline $50 \mathrm{t5}$ & $\begin{array}{l}\text { Wholesale and retail trade; } \\
\text { hotels }\end{array}$ & 10.6 & 14.5 & 25.8 & 280.92 \\
\hline $60 t 4$ & Transport and communication & 30.7 & 26.9 & 204.9 & 831.78 \\
\hline $65 \mathrm{t} 74$ & Financial intermediation & 10.8 & 17.4 & 35.2 & 398.05 \\
\hline $75 t 99$ & Public services & 13.7 & 23.5 & 29.0 & 2184.7 \\
\hline TOT & Total economy & 19.5 & 19.6 & 103.2 & 247.89 \\
\hline
\end{tabular}

Source: Estonian Business Registry database, authors' calculations 